\title{
Olavian Traces in Post-Medieval England
}

\author{
Karl Christian Alvestad
}

In 1918 Sir James Bird, clerk to the London County Council, mournfully noted that if the church of St Olave, Southwark, was destroyed and its parish abolished, it would mark the end of an almost nine-hundred-year-long history of St Olaf being a part of the landscape and life of Southwark, and that it would be the loss of an identity marker for the community connected to the church. ${ }^{1}$ His remarks were to no avail. During the following decade, the church was closed and torn down, and the parish split between its neighbouring parishes, including St Mary Magdalene, Bermondsey. ${ }^{2}$ The parishes in Southwark have since changed their borders several times and the majority of what was St Olave Parish today forms parts of St Mary Magdalene, with St Olave, St John and St Luke, Bermondsey. The current parish of St Mary Magdalene retained Olave in its name up until the 1970s. As a consequence of these changes the parish church of St Mary Magdalene houses some of the few surviving artefacts from St Olave, Southwark. ${ }^{3}$ Although the parish church of St Olave, Southwark, has been demolished, the church and the parish is an excellent starting point for the exploration of the survival and legacy of St Olave in Britain as it illustrates some of the changes and challenges faced by the Olavian traces in the 2oth century. St Olave might have been a significant saint in the Middle Ages, and the traces of his cult have through churches, images, two schools, and the name of a village, endured and become embedded in the landscape of Britain. This endurance reflects and mirrors many of the changes that have taken place in Britain, particularly in the post-medieval world.

1 James Bird and W.R. Riley, St Olave's, Southwark (London, 1918), p. 12; King Olaf II Haraldsson was elevated to sainthood in 1031 after his death in 1030, in a Nordic context he is most often referred to as St Olav or St Olaf, whereas in an Anglophone context-and especially in the British Isles-Olaf appears in an anglicised version of Olav, from the genitival Olaves, as St Olave or in some very rare occasions as St Ola (this use only occurs in Orkney in the British Isles to my knowledge). 'Olave' is used throughout this chapter in reference to the saint's cult and most of his dedications in England but, in line with other usage, 'Olaf' is used in references to the king himself and other dedications.

2 Mervyn Wilson, A Brief History and Description of Bermondsey Parish Church, St Mary Magdalen, with St Olave, St John and St Luke, Bermondsey (London, 1976), p. 21.

3 Wilson, Brief History and Description, p. 14. 
In this chapter I will therefore explore how, where, and if possible why, these Olavian traces survived, as well as how we might understand them. One of the key questions addresses by this paper is what causes have impacted the changes in the Olavian traces. The paper also asks whereas there are any wider trends that dictated the use and presentation of Saint Olave (Olaf) in the period between Queen Elizabeth I's accession to the throne and today.

In a brief work published in 1998, A Saint for All Nations, Simon Coupland explored the international dimensions of the cult of St Olave in the Middle Ages. ${ }^{4}$ His work gives an excellent overview of the Olavian cult, but it sheds little to no light on the centuries following the Reformation. His study identified many key elements of the development of the cult across Europe, and placed the cult in the British Isles in this wider context. Fifty years before Coupland, Bruce Dickins had demonstrated in his article "The Cult of S. Olave in the British Isles" that the cult of St Olave could be traced back to the 1050s in Britain. ${ }^{5}$ Dickins also demonstrated that there had been a number of new Olavian dedications in the 19th century, among other at Ramsey (Isle of Man), Lerwick (Shetland), Woodberry Down (London), and Bermondsey (London). ${ }^{6}$ These two studies have until now formed the core of the scholarship on the Olavian cult in Britain, but new additions to this study of saints and their place in the British landscape are now available. Elsewhere in this volume, Robert Higham convincingly suggests that the early cult of Olave has significant connections with the Anglo-Scandinavian aristocracy in England before the Norman Conquest, ${ }^{7}$ while Michael Hicks explores the place of the AngloScandinavian saints in the religious landscape of England after 1066 and into the late medieval period. ${ }^{8}$

Although theories for the origins for the Olavian cult in Britain have been presented, few scholars have considered the survival of these cult sites up to today, and the 19th- and 2oth-century revival of these Olavian traces. This chapter addresses this deficiency, and it explores the survival and developments of the Olavian cult, its sites and images in post-medieval Britain. This chapter focuses especially on the 19th- and 2oth-century Olavian traces and

4 Simon Coupland, A Saint for All Nations: The Cult of Saint Olaf Outside Norway (Trondheim, 1998).

5 Bruce Dickins, "The Cult of St Olave in the British Isles," Saga-Book of the Viking Society 12 $(1937-45), 5^{2-80 .}$

6 Dickins, "Cult of St Olave," p. 79.

7 Robert Higham, "The Godwins, Towns and St Olaf Churches: Comital Investment in the Mid11th Century," above, pp. 467-513.

8 Michael Hicks, "Leavings or Legacies? The Role of Early Medieval Saints in English Church Dedications beyond the Conquest and the Reformation," above, pp. 582-601. 
their wider cultural and social contexts. It will thus explore the mechanism that has supported an Olavian renaissance in the twentieth century.

While this chapter aims to explore the survival of Olavian traces in Britain, the accessibility of evidence and the constraints of length have only allowed an examination of evidence from London, Wessex and the Lake District. The inclusion of the later example is due to a particularly interesting dedication to St Olaf (with Old Norse-inspired spelling) at Wasdale Head in the Lake District, Cumbria. Although this chapter examines a limited number of traces, these traces provide an opportunity for further studies, and as such give some insight into the continuation of the Olavian traces throughout Britain. The selection of examples included in this chapter means that sites-such as the church of St Olaf in Poughill (Cornwall) and the Priory and village of St Olave in Norfolk among others-will not be examined in this context, ${ }^{9}$ but I hope one day to return to them and provide a more complete analysis of the Olavian cult and its traces in the British Isles. Through the selected dedication and traces the chapter will explore and examine how Olaf II Haraldsson is remembered, cultivated and perceived in Britain in this period. These dedications and traces survive today through the writings about the individual churches dedicated to Olave, and parishes these churches belong to. Many of these texts are results of the thoughts and inspirations of the parish councils or a member of the local communities, and can as such be seen as a statement of the local memory, identity and understanding of the role St Olave plays in their community. Accordingly this chapter engages with the memory and identity function the Olavian traces have played in the 2oth century. This will be of the utmost significance in the context of St Olave, Southwark, where although the church was dismantled, the community retained statements and identifiers to their previous religious identities.

\section{Continuity and Change —-Survival and Renewal: Surviving the Reformation in Britain}

Following the Lutheran reformation of Norway in $1536-37$, the centre of the Olavian cult at Trondheim, Norway, saw its shrine dismantled with pilgrimage and religious remembrance of St Olaf eradicated in the new Lutheran Church. These changes contributed to a decline in popularity for St Olaf in much of Europe including the British Isles. As a consequence of this and the dissolution

9 K. Rutherford Davis, St Olave's Priory, Herringfleet, Suffolk (London, 1949); note that 2othcentury changes to the county borders moved the village and priory of St Olave to Norfolk. 
of the monasteries in both Scandinavia and Britain in the mid-16th century, much of the knowledge about the wider cult of St Olave and its developments, was lost. It can today be suggested, due to extensive cross-referencing of a number of sources, that the Olavian cult in the Middle Ages had been significant and that the reformations of Norway and England has a major impact on this cult. In Norway, the shrine of St Olave was destroyed and the body of the saint was lost. ${ }^{10}$ Similarly, cult statues, reliquaries and texts were destroyed, confiscated or hidden. As a result, much that once was only survived in folklore and popular memory through place names or local myths.

Of course, this stripping of the altars was not an exclusively Norwegian experience. The English reformation can be seen as both a curse and a blessing for the Olavian cult: a curse in that an unknown number of objects may have been destroyed in the stripping of English churches as part of the iconoclasm of the Reformation; ${ }^{11}$ and a blessing in that the Marian revival of the Catholic Church in England saw a new cult statue being produced for St Olave, Southwark. ${ }^{12}$ Although this statue is now lost, the textual references to it provide information about the church at Southwark, and help to highlight the importance of the Southwark church in the religious landscape of London in a Catholic context. Yet, today little survives of the medieval representations of Olave in England; those that do survive can predominantly be found in manuscripts and textual sources. The majority of Olavian traces that survived the English reformation are church dedications such as the St Olave's church in York, Exeter, Gatcombe (Isle of Wight), Southwark, a number in London. ${ }^{13}$ These churches, and the names of those that have not survived, can be read as indicators of the popularity of St Olave in the Middle Ages, something Dickins, Higham, and Coupland have commented on. ${ }^{14}$ Many of the Olavian dedications that are now lost have left traces in the physical landscape of Britain through place names and artistic depictions of the saint, and they testify to the continuity of names and the longevity of identity markers such as parish

10 Øystein Morten, Jakten på Olav den Hellige [The Search for St Olaf] (Oslo, 2014), pp. 17-19.

11 Eamon Duffy, The Stripping of the Altars: Traditional Religion in England 1400-1580, 2nd ed. (London, 2005), pp. 381, 453 and 480.

12 Dickins, "Cult of St Olave," p. 68.

13 York: Henry Stapleton, The History of St Olave's Church York (York, 2002), pp. 6-7; Exeter: Dickins, "Cult of St Olave," p. 69; Gatcombe: Anon., St Olaves Church Gatcombe: A Short Guide and Souvenir (Gatcombe, 2010); James Evans, The Church of St Olave and Its Links with the Past, 2nd ed. (Gatcombe, 1966); Southwark: Bird and Riley, St Olave's, pp. 5-12; London: Phil Manning, "Our Own Church": Aspects and Images of St Olave's Hart Street, All Hallows Staining and St Catherine Coleman (London, 2014), pp. 3-12 and 48. Coupland, Saint for All Nations, pp. 7-16. 
churches and local dedications to saints. A crucial fact or consequence of this local identity is the happy accident that parish churches in Britain largely retained their medieval names, which supported by the continuity of settlement patterns have caused a retention of saints dedications, at least in the case of Olave, to remain in their original locations. In the Norwegian context such continuity is very rare. As such, these churches formed the foundation for the Olavian traces in the post-medieval period. To my knowledge, there were no new Olavian dedications until the 19th century. While three of these later dedications are explored to some detail at the end of this chapter, from the English reformation until the Great Fire of London in 1666, little is known about the developments of the Olavian traditions in Britain beyond a reference to the aforementioned Marian revival statue of St Olave dating from 1556-58 at the Church of St Olave, Southwark. What can be established is that in 1561 a school was established in the parish of St Olave, Southwark..$^{15}$ This foundation is today known as St Olave Grammar school, and takes its name from the parish it once belonged to. The founding of this school can be seen in a wider context of Elizabethan educational policies, according to R.C. Carrrington, ${ }^{16}$ and is not an anomaly among these but represent instead the norm. The details of the history of this school are investigated further below; for the present all that is necessary to be established is that the school was established before the Great Fire of London and its impact on the Olavian traces.

\section{The Great Fire of London}

During the Great Fire of London, three of the medieval St Olaf churches of the city burnt down, and only one, St Olave Hart Street, survived due to the creation of firebreaks around it and the Navy Office, ${ }^{17}$ changing the face of the Olavian traces in London. Samuel Pepys narrates through his diary how the church was saved, "blowing up of houses in Tower-streete, those next the Tower $[\ldots]$ and then it was east to quench what little fire was in [the ruins of the houses torn down for protection of the Navy Office]."18

15 R.C. Carrington, Two Schools: A History of the St Olave's and St Saviour's Grammar School Foundation (London, 1962; repr. 1971), p. 34.

16 Carrington, Two Schools, pp. 14-19.

17 Manning, "Our Own Church," p. 36.

18 The Diary of Samuel Pepys, ed. Henry Benjamin Wheatley, 5 (London, 1923), p. 399. 
Pepys' diary contributed to the church of St Olave Hart Street becoming a centre for pilgrimage, as a mid-2oth-century commentator claimed. ${ }^{19}$ Following the fire's destruction St Olave Old Jewry was restored, but St Olave Silver Street and St Nicholas Olave were both destroyed and the parishes united with neighbouring parishes. The Fire of London had a significant impact on both the expression of and content of the religious landscape of London. Another 2oth-century commentator, Eileen Gray, noted that St Olave Hart Street was one of only eight surviving pre-1666 churches left in the City of London. ${ }^{20}$ As such the three Olavian churches lost in the Fire were not alone, and are more representative of the development of churches in the city than the odd survivor in Hart Street. St Olave Old Jewry was the only one of the fire-damaged Olavian churches that was included in Christopher Wren's rebuilding plan. ${ }^{21}$ The church was restored and was in use until 1884, when the parish was united with the neighbouring parishes following a dramatic population decrease. As a result of the unification of the parishes, the Olavian dedication was transferred to the neighbouring parish of St Margaret Lothbury, another Wren church nearby. ${ }^{22}$

Following the fire of London, there is a gap in the sources for the Olavian cult in Britain, the next thing we hear is that in 1736 St Olave Southwark was granted funds to be restored after years of decline, in what W.R. Riley claimed in 1918 was a classic example of the post-Wren late English Renaissance style drawing inspiration from St Martin-in-the-Fields and St Paul's cathedral. ${ }^{23}$ Despite the 18th-century restoration, the church and its community struggled in the 19th century due to changes in the population of the parish.

\section{Restoration and "Viking Awareness" in Georgian and Victorian England}

Barbara Yorke argued in 2009 that the Victorians were fascinated by the Vikings through two key strands: (1) through the history of the localities, and (2) a

\footnotetext{
19 A. Powell Miller, Parish Church of St Olave, Hart Street: An appeal for the restoration of the Church (London, 1951), p. 5.

20 Eileen Gray, St Olave's Church (London, n.d. [c.1950]), p. 5 .

21 John Christopher, Wren's City of London Churches (Stroud, 2012), pp. 58-59.

22 Church of England, Diocese of London, Amended Proposals for a Scheme for Union of the Rectory of St Margaret Lothbury with St Christopher-le-Stocks and St Bartholomew Exchange with the united rectory of St Olave Old Jewry with St Martin Pomeroy, St Mildred Poultry and St Mary Colechurch (London, 1884), p. 2.

Bird and Riley, St Olave's, p. 18.
} 
wider concern about the perceived antiquity of European nations. ${ }^{24}$ This first of these strands are also seen in the 19th century when it comes to the Olavian traces. The best example for this is perhaps St Olave Southwark, both the parish and the church, but it also applies to a wider programme of restorations that seems to have taken place in the Olavian churches. It is worth noting here that the 19th century saw the re-discovery and compilation of Viking history, and although the Vikings were part of popular culture in Britain at this point, they were, according to Andrew Wawn, a distinctly novel element in British and European Culture. ${ }^{25}$

In the years since the Great Fire of London, St Olave Southwark, which had not been damaged in the Fire as it was on the south side of the River Thames, had apparently started to show signs of age. The medieval church was refurbished and extensively altered in 1736. Riley opined that, like Wren's late 17thcentury church of St James's, Piccadilly, and James Gibbs' early 18th-century church of St Martin-in-the-Fields, the new church of St Olave was "designed on [a] Basillica Plan"26 (sic.), and went on to state that it was a representative of the Late English renaissance in church architecture. This redesign of the church represents a major investment of $£_{5}, 000$ by Parliament in response to the state of the church. A fire in 1843 in the building damaged the interior, meaning further works were required. The physical restorations, investments and rebuilding in this church indicates not only an interest in the church itself, but also a conscious connection to the building and the parish, ${ }^{27}$ a connection between the parishioner and the location, and reaffirms the place of Olave in the London cityscape.

Alongside these investments the identity of the parish seems to have been kept alive, and to some extent evolved. Although the sources we have available from this period are few, an interesting statement of the local identity is a small publication from 1886, by the Reverend S. McDaniel, a Catholic priest based in Southwark. ${ }^{28}$ McDaniel presents the history of the Catholic mission

24 Barbara Yorke, "The 'Old North' From the Saxon South in Ninteteenth-Century Britain," in Anglo-Saxons and the North: Essays Reflecting the Theme of the 1oth Meeting of the International Society of Anglo-Saxonists in Helsinki, August 2001, ed. Matti Kilpiö, Leena KahlasTarkka, Jane Roberts, and Olga Timofeeva (Tempe, AZ, 2009), pp. 131-50, at p. 148.

25 Andrew Wawn, The Vikings and the Victorians: Inventing the Old North in NineteenthCentury Britain (Cambridge, 2002), pp. 3-9.

26 Bird and Riley, St Olave's, p. 18.

27 K.D.M. Snell, Parish and Belonging: Community, Identity and Welfare in England and Wales 1700-1950 (Cambridge, 2009), p. 441.

28 S. McDaniel, Life of St Olave, Martyr, and King and Patron Of Norway (London, 1886). 
in Southwark, taking the opportunity to claim that the Catholic parish of Our Lady of La Salette and St Joseph, Southwark, was the rightful successor of the medieval parish of St Olave, and at a result he and the parish should place themselves under Olave's protection. ${ }^{29}$ McDaniel's prayer: "St Olave, Pray for us," ${ }^{30}$ follows on from a concise but detailed theological account of intercession, and above all a claim that St Olave watches over his parish and the locality of Southwark. McDaniel substantiates this by pointing to the Miracle of the healed knight at St Olave, Southwark, recorded in a number of the versions of the medieval hagiography of St Olave, Passio et miracula beati Olavi. ${ }^{31}$ This account not only indicates the awareness of Olave by religious communities in the area, but also that the sources regarding his life were being circulatedeven if McDaniel did not state which texts he drew on-among at least some of the religious elite.

Although the miracle of the English knight is not mentioned by Thomas Carlyle in his The Early Kings of Norway, he does highlight the presence of two St Olave churches in London, one of which Carlyle explicitly states is St Olave Southwark. ${ }^{32}$ Carlyle further highlights that these churches have been the site of miracles, ${ }^{33}$ suggesting that St Olaf's miracles in London were fairly well known among authors interested in Olaf in the 19th century.

The link between the parish of St Olave Southwark, and the miracle is reiterated in the 1918 account. It was used as an argument for why the church should be saved and not demolished or sold. ${ }^{34}$ The crisis of St Olave Southwark at the beginning of the 2oth century, was one faced by other London parishes as well, including St Olave, Silver Street, decline in population and changing demographics. This situation was not helped by the presence of the Catholic community of Rev. McDaniel just a stone's throw from the parish church. The decline was so marked that the parish was unable to support any restorations of the church, and the church was declared redundant in 1926, with the site sold off in 1928, and the parish divided between its neighbours.

\footnotetext{
29 McDaniel, Life of St Olave, pp. 2-3.

3o McDaniel, Life of St Olave, p. 3.

31 A History of Norway and The Passion and Miracles of the Blessed Olafr, trans. Devra Kunin and ed. Carl Phelpstead (London, 2001), p. xxxviii.

32 Thomas Carlyle, The Early Kings of Norway and An Essay on the Portraits of John Knox (London, 1875), p. 31.

33 Carlyle, Early Kings of Norway, p. $15^{2}$.

34 Bird and Riley, St Olave's, pp. 6-8.
} 


\section{Identity and Place: The Saint, the Viking, and the Norseman as Identity Marker in 2oth-Century Britain}

Following the dissolution of St Olave Southwark, the remaining parish community in Southwark sought to protect the Olavian tradition of the location resulting in a number Olavian dedications, including buildings on the site of the former church. By setting these dedications in context of the closure of St Olave Southwark they represent a survival of the Olavian tradition through traces in the landscape of the city. Traces such as street names, the moving of dedications to new churches, or continuity of symbols have been seen by Rudy Koshar as elements of a memory landscape. ${ }^{35}$ As such, these dedications can be interpreted as an extension of Pierre Nora's notion of Lieux de mémoire ${ }^{36}$ and, through that, a manifestation of the cultural memory of the community. This would imply that Olavian dedications of the 2oth century, both in London and elsewhere, can potentially be seen through the lens of community identity and cultural remembrance within the community that commissions the dedications. Such a conscious memory construction can be seen in some of the 2oth-century Olavian dedications.

\section{Southwark Cathedral: St Olaf House and New Churches in London}

Following the closure and dismantling of St Olave Southwark, the bishopric of Southwark transferred the name and dedication St Olave to a new mission south of London, in Mitcham. This transferral came as a consequence of the new Mitcham parish receiving parts of the profits from the sale of the dismantled Southwark church. According to Keith Penny, the only condition of these funds were that the new parish would assume the old dedication of St Olave's, through which it would ensure a continuity within the bishopric, acknowledging the past of the region and tapping in to the identity of the community on the south shore of the Thames. ${ }^{37}$

35 Rudy Koshar, From Monuments to Traces: Artifacts of German Memory 1870-1990 (London, 2000), p. 9.

36 Pierre Nora, "Between Memory and History: Les Lieux de Mémoire," Representations 26 (1989), 7-24.

37 Keith Penny, The Church of Blue Columns, Anglo-Catholicism in a New District: St Olave, Mitcham, 1928-1939 (London, 2013), p. 6. 


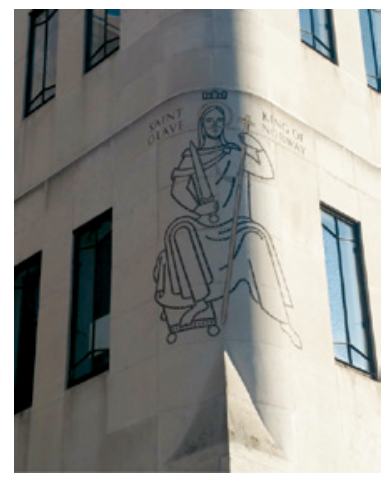

FIGURE 28.1

Mosaic of "Saint Olave, King of Norway" on the corner of St Olaf House, Southwark

(C) KARL C. ALVESTAD

This continuity of dedication and tradition, although invented, fits within a wider set of statements of Olavian continuity in the Southwark area. Although the parish of St Olave was abolished and split in several parts, the local landscape still presents reminders in its fabric to the lost church and its parish. The site of the church is today St Olaf House in Tooley Street, a street whose name is derived from that of St Olaf. ${ }^{38}$ At one corner of St Olaf House a visitor to the area can today find St Olave's Stairs, a present reminder of the old name of the location. Tooley Street, although an ancient street, presents the visitor also with another reminder of the past of the location, a major mosaic relief on the corner of St Olaf House (see Fig. 28.1). This depiction is not as surprising in its placement as in its iconography, but it strengthens the sense of Olavian continuity at the site and quite literally cements Olave in the cityscape of Southwark.

As with the church of St Olave, Southwark, St Olave's School, a pre-Great Fire Olavian institution noted above, was an integral part of the cityscape of the parish. Founded in 1561, and re-confirmed in 1571 as St Olave Grammar School, ${ }^{39}$ the school represents in many ways both the beginning of the new Olavian traditions as well as the continuation of the old. The school was established in the parish of St Olave, Southwark, and thus took the name of the parish of its origins. Such an act of naming policy was nothing new, nor was it a

38 See Higham, "Godwins, Towns and St Olaf Churches," above, p. 505.

39 Carrington, Two Schools, pp. 34-35. 
representation of a cult continuation with reference to Olaf; instead is was a statement of identity and locality. The school was situated in the parish until the second half of the 2oth century, when it moved to Orpington where it remains today. ${ }^{40}$ Although it moved, it still carried the name and some of the symbols of the school and its original parish.

Even though St Olave Grammar School has since moved from the parish, its dedication - and that of its sister institution, St Saviours and St Olave Grammar School—still recalls the Olavian origins of their foundations through the symbols used at the schools. The Old Olavians, the former students of Olave proper, use an emblem displaying an open crown and an axe, ${ }^{41}$ two of the most common attributes connected with St Olaf in artistic depictions, ${ }^{42}$ whereas the school of St Saviours and St Olave has incorporated this symbol in to their school crest. ${ }^{43}$ These institutions continue today the educational traditions of the parish of St Olave, Southwark, and through their imagery they present a direct link to the Olavian traditions of Southwark.

As an extension of these traditions and the links with their Southwark past, the former pupils of St Olave Grammar School formed the Old Olavians association in the late 19th century. Their magazine Olavian, first published in 1896, is a treasure trove for researchers exploring the history of the school. ${ }^{44}$ The Olavians and St Olave Grammar School represent today a statement of continuous tradition from Southwark, one which taps in to the traditional iconography of King Olaf through the Crown and the Axe.

\section{Depicting the Saint-King}

Despite the continuity of St Olave in a school setting, there were evidently fears that following the early 2oth-century destruction of St Olave's Church Southwark, the long tradition of Olavian presence in Southwark would end. As

$40 \quad$ Carrington, Two Schools, p. 249.

41 Carrington, Two Schools, p. 13; Old Olavians Website, <www.oldolavians.net> (accessed 19 Feb., 2017).

42 Margrethe Stang, "Helgenkongen og Alterbilder" [The Saint King and the Altar Piece], in Helgenkongen St Olav I kunsten [Depictions of St Olaf in Art], ed. Øystein Ekroll (Trondheim, 2016), pp. 27-53, at pp. 31-33.

43 St Saviours and St Olave's School homepage, <http://www2.ssso.southwark.sch.uk> (accessed 19 Feb. 2017).

Carrington, Two Schools, p. 275 . 


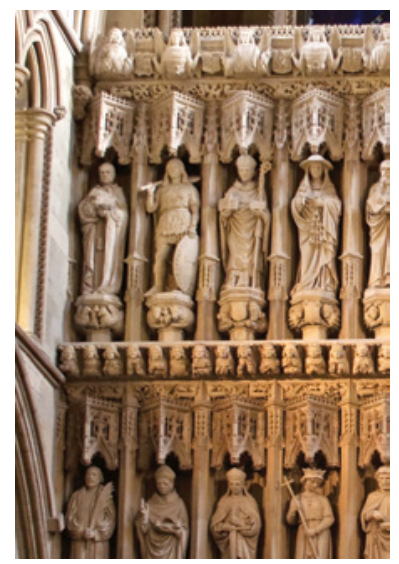

FIGURE 28.2

Statue of St Olave (second from left on the upper tier) as part of the altar screen of Southwark Cathedral

(C) TONY HISGETT, BIRMINGHAM, UK [CC BY 2.0

(HTTPS://CREATIVECOMMONS.ORG/LICENSES/BY/2.0)]

a result a number of interesting steps were taken to retain a sense of Olavian continuity for the area. At the site of St Olave's Church a new building, opened in 1932, externally gave a nod to the origins of the parish and its name. For on the corner of Tooley Street and St Olave's Stairs the new building presented a mosaic relief of St Olaf. ${ }^{45}$ However, this depiction presents a rather interesting image of the Saint; he is seated whilst holding a long cross-topped staff in one hand, and a naked sword in the other (see Fig. 28.1). The closest similarity to this depiction comes from Southwark Cathedral, where a statue from the same period can be seen on the altar screen (Fig. 28.2). The sword is an uncommon attribute for St Olave, who is most commonly depicted with an axe. The use of the axe is can be seen in a number of contemporary depictions in London among other in the stain glass window of St Olave Hart Street and on the statue found on the face of Norway House just off Trafalgar Square. ${ }^{46}$

The majority of Olavian images in London are modern, taking inspiration from the medieval Olavian iconography. Among these depictions the stain glass window in Hart Street, which in 2015 was presented by Caroline Swash as one of the 100 best stained glass sites in London, ${ }^{47}$ is perhaps the best example of iconographic continuity in the image of Olave. The Hart Street image of

45 Historic England, Historic England Website: "St Olaf House," < https://historicengland.org .uk/listing/the-list/list-entry/1385977> (accessed 19 Feb. 2017).

46 Karl Alvestad, "Den nasjonal Olav" [The National Olaf], in Helgenkongen St Olav I kunsten, ed. Ekroll, pp. 191-214, at p. 204.

Caroline Swash, The 100 Best Stained Glass Sites in London (London, 2015), p. 92. 
Olave was made by Arthur Buss (1909-99) presents a man standing, ${ }^{48}$ crowned and majestic; he holds the traditional axe and at his feet lays a dragon, a symbol often interpreted as the evil within himself that Olaf overcome before the battle of Stiklestad. This image draws directly on images surviving from the late medieval Hanseatic tradition of depicting Olaf, where the saint is depicted standing with a dragon under his feet, and holding the axe. ${ }^{49}$ This image was also absorbed by the Norwegian artist Gustav Vigeland, who in 1898 designed the quintessential image of St Olaf in a modern context; where the king stands crowned and holds an Axe, and Orb and under his feet rests a dragon with his own face. In a Norwegian context, the statue designed by Vigeland marked the height of Gothic revival in art and architecture. ${ }^{50}$ Buss's stained glass window further presents a tantalising clue to the modern Olavian tradition, both in Britain and throughout the world. For in the frame underneath the depiction of St Olaf is the crest of the modern Norwegian royal house and the monogram of Haakon VII of Norway (1872-1957), the last Norwegian king to be crowned as a successor of Olaf. Haakon's monogram is an acknowledgement of Haakon's use of St Olave's church Hart Street as his parish Church for parts of his exile in London. The monogram also illustrates the link between Olaf and the Norwegians in the 2oth century, and to them [us] Olaf is a key cultural emblem.

However, the Olavian images in London also include a number of depictions of Olave which are significantly different from the Saint of St Olave Hart Street; chief among these is the mosaic relief on St Olaf House in Southwark, on the site of the ancient St Olave church in Southwark. The relief shows Olave seated, robed and crowned, holding a cross and a sword; two attributes that plausibly refer to the church, and the episode in the sagas wherein King Olaf is said to have taken part in the defence of London in 1014, pulling down London Bridge. ${ }^{51}$ But here, St Olave is not presented wearing Viking or medieval garbs, instead he cloak and tunic is draped to look like closer to a classical costume than an early medieval one. As mentioned above, the sword this Olave statue wears is a rather unusual attribute to the king, but London is also the home of three other depictions from around the same date all showing St Olave with a sword instead of an Axe. Two of the more prominent ones are the statues by

48 Swash, The 100 Best Stained Glass Sites, p. 92.

49 Stang, "Helgenkongen og Alterbilder," pp. 43-45.

50 Alvestad, "Den nasjonal Olav," pp. 195-96.

$5^{1}$ Snorri Sturluson, Heimskringla II: Óláfr Haraldsson (The Saint), trans. Alison Finlay and Antony Faulkes (London, 2014) p. 10. 


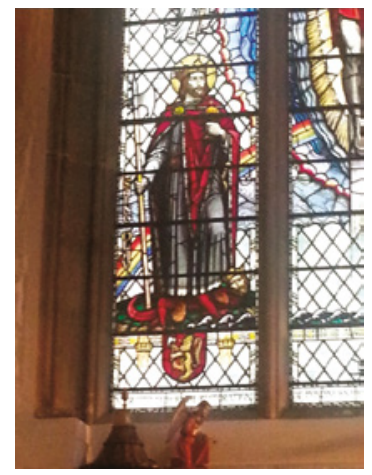

FIGURE 28.3

Stained glass window depicting St Olave made by Arthur Buss, in St Olave Hart Street, London

(C) KARL C. ALVESTAD

Gustav Lærum on the façade of Norway House, and in the hallway of the Norwegian Seamen's church in Rotherhithe, dedicated in 1927 to "St Olav."52 These two statues are exactly the same, and show Olave standing, dressed as a Viking with a big cross on his chest and a sword with the sword point in the ground in front of him; in this depiction Olave is the Christian king and nation-builder of Norwegian historical tradition, the founder and defender of Christianity in Norway. This image is key to the historical understanding of Olave/Olaf in Norway, and also key to why Norwegian society and settlements have turned to Olave for symbols in exile or following migrations.

The final Olavian image in London can be found very close to the site of the former St Olave Southwark, namely in Southwark Cathedral, where the altar screen today includes a statue of Olave in the romanticised image of a barbarian'. Moreover, the Southwark Cathedral Olave presents a man holding his sword over his right hand shoulder, dressed in some sort of skin, whilst holding his shield with a cross, against his left leg. Few of the attributes given to Olave in this statue are normally used to identify him and the identification of this statue as St Olave is therefore entirely reliant on local guiding literature. The cathedral's tradition, recorded in its guidebook, recalls that this Olavian figure (see Fig. 28.3), was made in the 1920s or 3os, the same time as the Olavian dedication of the bishopric moved from Southwark or Mitcham as discussed above. The plaque for the screen corroborates this story, for it suggests the statue was commissioned and produced before St Olave Southwark was dismantled. Yet, 
the plaque also tells the reader that Olave sailed up the Thames and attacked England in 994 as an enemy of Æthelred 'the Unready', before returning in 1014 as an ally of the same king, and helped save London. The plaque claims: "he was a man of war but embraced the Christian religion and became a devotee," a statement which possibly can be attributed to both Olaf I (i.e. Olaf Tryggvason, who died c.100o) and Olaf II of Norway. For through its introduction of St Olave, the plaque presents the two Olafs as one person, suggesting that the author of the plaque was familiar with key events in the Viking age, whilst at the same time not have access to, or used the sagas. The author of the plaque seems to the only author to confuse these two kings, whereas the contemporary Rev. S. McDaniel, James Bird and Philip Norman all seem to have managed to separate these two kings. The knowledge about the Viking past of Olaf, and especially his supposed role in the defence of London against the Danes in 1014, is a key feature in most narratives about Olave from the beginning of the 2oth-century in London. ${ }^{53}$ To these narratives, Olaf is a link to both the Vikings and to the Anglo-Saxon past, whilst he also was an accepted symbol for the newly-independent Norwegian state.

\section{London's Norwegian Olaf}

Throughout the 19th century, Norwegian society had awoken to the possibility of political independence, and had rediscovered its Viking and medieval past. As part of this, the history of Olaf II Haraldsson was transmitted among the population through textbooks and national commemorations. ${ }^{54}$ Following Norwegian independence from Sweden in 1905, Norway needed an embassy in London, and the Norwegian community in the city needed a place to gather. In 1924, the Norwegian community in London received its first centralised 'home', in Norway House just off Trafalgar Square, where one of the two Olave statues by Gustav Lærum was placed above the doorway. ${ }^{55}$ By placing the image of Olave on the façade of the building, Olave House, home of both the Norwegian Club and the Norwegian Embassy, linked St Olave directly to Norway and

53 Philip Norman, St Olave's Hart Street (London, 1905), p. 93; Wilson, A Brief History and Description, p. 21.

54 Karl Christian Alvestad, "Kings, Heroes and Ships: The Use of Historical Characters in Nineteenth- and Twentieth-Century Perceptions of the Early Medieval Scandinavian Past," Ph thesis, University of Winchester, 2016 (currently in preparation for publication).

Alvestad, “Den nasjonal Olav," pp. 204-06. 
claimed him as a Norwegian saint. To some extent, this distorted the Olavian tradition in Britain. The re-dedications and use of Olave in London and throughout Britain had through the centuries established Olave as a saint who happened to be a Viking and a Norwegian, but whom in the eyes of Rev. S. McDaniel $^{56}$ and Rev. R.K. Haslam ${ }^{57}$ was an example for the devotion and religious dedication.

The 'Norwegianness' of St Olave was not stressed until this point; instead Olave seems to have taken on a modern nationality around $1925^{-27}$, when the Norwegian seamen's church was established in Southwark and named St Olaf's Church. St Olaf's Church is the home of the second Lærum statue, and together with Norway house must have been at the heart of the Norwegian community in London. The link between Olave and Norway is further expressed in the context of St Olave Hart Street, which, following its destruction during the Blitz, tapped into Olave's Norwegianness and the connection between the church and Samuel Pepys to fund the reconstruction. A. Powell Miller, the rector of the parish, noted in 1951 that as part of the reconstruction of the Church, the church had received a piece of stone from Trondheim Cathedral "built over the tomb of St Olaf, and this is to be incorporated in the new building."58 Through this incorporation, St Olave Hart Street reinstated the bonds between the heart of the Olavian cult and some of the sites of Olavian traces in Britain. As such the medieval bonds described by Coupland in 1998 are being rediscovered and re-constituted in the modern age.

\section{Wasdale Head - the Odd One Out? Or the Example that Confirms the Rule?}

At the foot of Scafell Pike in Cumbria, the tallest point in England, within a cluster of trees not far from Wastwater, England's deepest lake, lies what to some might sound like the odd one out of the Olavian traces in Britain, the small St Olaf Church at Wasdale Head. St Olaf Church gained its name as late as 1977, and is thus the newest dedication to Olave (in this case, 'Olaf') in Britain.

First attested in the 16th century but bearing no known dedication until 1977, the dedication to St Olaf on 23 March 1977 was an act of public

$5^{6}$ McDaniel, Life of St Olave, pp. 28-29.

57 Penny, The Church of Blue Columns, p. 92.

58 Powell Miller, Parish Church of St Olave, p. 5. 
remembrance and identity construction, whereby the Bishop of Carlisle and the church embedded the Viking past of the parish into the very name of the church. There is no evidence that St Olaf ever visited Cumbria, nor did Dickins find any traces of Olave surviving from the Middle Ages in this part of Britain, but the region is well known for its many Viking artefacts and Norse place names. Among these artefacts is the Gosforth Cross outside St Mary's Church in Gosforth, approximately 9 miles away from Wasdale Head and in the same parish as St Olaf's Church. Interestingly, the church's 2002 booklet, narrating the local history and the history of the church, claims: "It is more than likely that the dalesfolk owe their Christian heritage to this Viking Saint." 59

Although unsubstantiated (and the booklet's subtitle, "Maybe True, Maybe Not," ought to give historians pause for thought!), this claim sheds an interesting light on what at least one parishioner believed their own religious origins to be, and the author of the pamphlet Bill Bailey makes a point of stating that it was the parishioners who initiated the "re-dedication" of the Church. ${ }^{60}$ As such the community at Wasdale Head has made an interesting statement to the world: to them their Viking origins are intrinsic to the landscape, their identity and to their site of worship. The church and its name St Olaf, which is a modern rendering of the Old Norse name Oláfr or the anglicised Olave, are at the centre of the community at Wasdale Head, and as such it shares many parallels with St Olave Southwark and St Olave Hart Street. For the church and the community, and the saint and the community have become intrinsically linked to a sense of place and identity; unlike the two London parishes, St Olaf at Wasdale Head is a modern creation in its dedication, but it shares key similarities with the two other churches. Firstly, all three of the churches share sense of historical origins in the 11th century, with Bill Bailey claiming that the current church at Wasdale Head is the same as the one built around the turn of the millennium (there is a local tradition that Viking ship timbers survive in the roof). ${ }^{61}$ St Olave Southwark is attested in the 11th century, ${ }^{62}$ whereas a document from 1109 refers to a church of St Olave near the tower. ${ }^{63}$ This latter reference is taken by some to be linked to St Olave Hart Street which is some $400 \mathrm{~m}$ from the Tower of London. Secondly, in line with the claims of Riley

63 Bryan Corcoran, Guide to St Olave's Hart Street, in the City of London (London, 1908), p. 111. 
and Bird, ${ }^{64}$ as well as Bryan Corcoran, ${ }^{65}$ Bailey claims that the churches of St Olave lay at the centre of a Viking-Norse settlement and that its community in Wasdale Head is a continuation of this settlement. Bailey highlights the links between the Vikings and Wasdale Head as a justification for the Olavian dedication. ${ }^{66}$ Indirectly Bailey makes St Olave an identity marker for Wasdale Head alongside the majestic surroundings of the church. This idea of a church as a marker of a community identity is also embedded in the 1918 report about St Olave Southwark, as such the symbols and ideas around saint and place in the modern British landscape is nothing new. Bailey describes in a sense the creation of a memory site at the re-naming of the church of Wasdale Head in 1977, a memory site that is designed to remind both locals and visitors of the real and perceived Viking heritage of the community. Although the church at Wasdale Head has taken the name of St Olaf, the church, to my knowledge, has no depictions of the saint. This might be due to the size of the church and the lack of space available, yet through its projected 'vikingness' the image of St Olaf is projected through the writings of Bailey and the dedication it accompanies creating a place and trace of Olaf that is unmistakably part of the Olavian traditions of Britain.

\section{Conclusion: Olavian Traces as Memory and Manifestation of Ages Past}

From the first dedications of the late Anglo-Saxon period, through the Middle Ages and the Reformation, a number of sites in Britain have been connected with the name Olave/Olaf. Their destiny and survival have closely followed the wider historical events in both England and in the United Kingdom as a whole. From the Great Fire of London through the bombs of the Second World War, the Olavian traces of Britain have survived, flourished and had a direct impact on the landscapes of Britain today. Although the majority of London's Olavian churches are now gone, their memory is still preserved in the cityscape through street names, plaques, and art. In other parts of Britain Olavian traces have shared the destiny of those in London, with some getting lost, whilst new ones are added. Two of the oldest, York and Exeter, still remain as prominent reminders of a time when the Olavian tradition, as now, was very much

64 Bird and Riley, St Olave's, p. 5.

65 Corcoran, Guide to St Olave's Hart Street, p. 111.

66 Bailey, The Vikings, Wasdale Head, p. 40. 
connected with the Vikingness or Norseness of the saint and the identity of the locality in which the dedication was placed.

\section{Acknowledgements}

I am grateful to Bob Higham, Ryan Lavelle, and Simon Sandall for some useful comments. This chapter is inspired by Barbara Yorke's work on AngloSaxonism, particularly on the 1901 commemoration of King Alfred, The King Alfred Millenary in Winchester, 1901, Hampshire Papers 17 (Winchester, 1999). It is therefore greatly indebted to Barbara's mentoring and guidance throughout my studies. 